\title{
Biofouling of ultrafiltration membrane by dairy fluids: Characterization of pioneer colonizer bacteria using a DNA metabarcoding approach
}

\author{
Julien Chamberland, Marie-Hélène Lessard, Alain Doyen, Steve Labrie, and Yves Pouliot ${ }^{1}$ \\ Department of Food Sciences, Dairy Research Center (STELA) and Institute of Nutrition and Functional Foods (INAF), 2425, rue de l'Agriculture, \\ Université Laval, Québec, Canada G1V 0A6
}

\begin{abstract}
Biofouling of filtration membranes is a major quality and performance issue for the dairy industry. Because biofilms that survive cleaning cycles become resistant over time, prevention strategies limiting the adhesion of bacteria to membranes should be prioritized for sustainable control of biofouling. However, this cannot be achieved because the pioneer bacteria colonizing these membranes are still unknown. Consequently, the objective of this study was to characterize pioneer bacteria on the filtration membrane surface and to measure the effect of filtration operational parameters on their diversity. Thus, milk and cheese whey were filtered for $5 \mathrm{~h}$ in concentration mode at 10 and $40^{\circ} \mathrm{C}$ using a laboratory-scale crossflow filtration system equipped with flat-sheet ultrafiltration membranes. Pioneer colonizer bacteria found on membranes after a chlorinated alkaline cleaning cycle were identified using a metabarcoding approach targeting the $16 \mathrm{~S}$ ribosomal RNA genes. Our results suggested that prevention strategies targeting biofouling should consider the nature of the filtered fluid and the feed temperature (36.15 and $5.09 \%$ of the variances observed on membranes, respectively), as well as the microbial environment of the dairy processing plant. In the future, it is hypothesized that cleaning prevention strategies will be specific to each dairy processor and their operational parameters.
\end{abstract}

Key words: dairy processing, ultrafiltration, biofilm, pioneer bacteria, metabarcoding

\section{INTRODUCTION}

Membrane fouling by milk components is an important issue at an industrial scale because it causes a loss of efficiency, increases cleaning time, and leads to high replacement costs (Anand et al., 2014). For the dairy

Received August 5, 2016.

Accepted October 6, 2016.

${ }^{1}$ Corresponding author: yves.pouliot@fsaa.ulaval.ca industry, biofilm formation on membranes is now an issue as important as fouling by chemical dairy constituents (Anand et al., 2014). Biofilms are generated by the initial adhesion of bacteria to a conditioning film that forms quickly on membranes at the beginning of the filtration process (Mittelman, 1998). As these bacteria grow, they develop a community that produces extracellular polymeric substances, forming a complex matrix called a biofilm that reduces membrane performance (Flemming, 1997; Herzberg et al., 2009). Within the biofilm environment, bacteria develop increased resistance to environmental stress. This situation is detrimental for dairy processors because biofilms survive membrane cleaning cycles (Anand and Singh, 2013; Anand et al., 2014). Throughout a membrane's lifetime, biofilm build-up causes the continuous inoculation of filtered fluids (Tang et al., 2015) and the release of enzymes, affecting the overall quality of retentates (Teh et al., 2014).

Over time, bacteria in biofilms develop resistance to cleaning cycles, which may be explained by the adaptation of bacteria to sanitizing agents (Pan et al., 2006). Consequently, prevention strategies, including pre-treatment of the feeds before filtration or selection of operating parameters that reduce bacterial adhesion to membranes, may be more efficient than treating the fluids to be filtered (Simões et al., 2010). In the dairy industry, fluids generally undergo heat treatment (pasteurization) before filtration to reduce their microbial load. However, pasteurized fluids still contain diverse viable bacteria (Quigley et al., 2013). After adhering to membranes, these bacteria can multiply on-site over time using nutrients available in the fluids being filtered to grow on membranes during long industrial processing times (18 to $24 \mathrm{~h}$; Flemming, 1997).

In recent years, different membrane coatings have been developed to reduce bacterial adhesion to membranes (Tang et al., 2015). However, independent of the type of membrane used, bacterial adhesion to membranes and the initiation of biofilms are instead related to the type of microorganisms found in the filtered fluid (Vanysacker et al., 2014). Indeed, a high-throughput 
sequencing approach found evidence that the diversity and composition of bacterial communities formed on cleaned industrial spiral-wound membranes used in the dairy industry were influenced by the inherent microbial composition of the filtered fluids, which, in turn, were modulated by the treatments used before filtering (pasteurization, bleaching of the whey, UF) (Chamberland et al., 2016). Several operating parameters were investigated during filtration that were found to affect the composition and incidence of biofilms on membranes, notably the feed temperature (Farhat et al., 2016), the concentration of the feed and the linear flow velocity (Vrouwenvelder et al., 2009), or the membrane material (Vanysacker et al., 2014). As far as possible, an exhaustive list of operating parameters should be taken into account to design an efficient cleaning strategy. However, little is known about which bacteria should be targeted, depending on the combination of operating parameters, to slow down the initial formation of biofilms on membranes, which is crucial for controlling biofouling (Simões et al., 2010).

Consequently, this study investigates biofilm formation in a controlled environment. A laboratory-scale crossflow filtration system was designed to measure the effect of various operating parameters (nature of the filtered fluid, feed temperature, and cleaning cycle) on the diversity of pioneer colonizer bacteria on membranes. Whole raw and pasteurized milk, and fresh and pasteurized cheese whey from the same batch lot of whole raw milk were filtered. Fouling was assessed by measuring changes in UF permeation flux over time and used a metabarcoding approach targeting the $16 \mathrm{~S}$ ribosomal RNA (16S rRNA) gene to identify pioneer colonizer bacteria adhering to UF membranes.

\section{MATERIALS AND METHODS}

\section{Ultrafiltration Experiments: Laboratory-Scale Model System}

A filtration system (Figure 1) consisting of a $10-\mathrm{L}$ stainless steel feed tank (double wall), positive displacement diaphragm pump (M-03S Hydra-Cell, Wanner Engineering Inc., Minneapolis, MN) and 4 parallel crossflow filtration cells (CF042, Sterlitech, Kent, WA) made of polytetrafluoroethylene with $42-\mathrm{cm}^{2}$ filtration surface area. All pipes and fittings were stainless steel except for the polyvinyl chloride fittings used to connect the retentate panel mount acrylic flowmeter. The feed temperature was maintained by circulating water from a temperature-controlled water bath (RM20, Lauda, Lauda-Königshofen, Germany) through the double wall of the feed tank. A restriction valve (Swagelok, Solon, $\mathrm{OH}$ ) at the outlet of the filtration cells controlled the pressure in the system. Two pressure gauges (Swagelok) measured the inlet and outlet pressures of the retentate in the cells. Flat-sheet polyethersulfone UF membranes with a molecular weight cut-off of $10 \mathrm{kDa}$ (ST membranes, Synder, Vacaville, CA) were used for all filtration experiments. Membrane coupons were cut from a square foot of membrane the day before the first filtration and were stored at $4^{\circ} \mathrm{C}$ in a $1 \%$ (wt/wt) sodium metabisulfite solution until filtration.

\section{Experimental Conditions}

The UF system was disinfected as described by Vanysacker et al. (2014) before each experiment by circulating a $70 \%$ ( $\mathrm{vol} / \mathrm{vol}$ ) ethanol solution with the following modifications: (1) the disinfection procedure was carried out without the membranes to avoid any surface modification of the membranes; (2) its duration (30 min) was shorter because it was performed as an additional safety measure and was not required in the cleaning protocol provided by the manufacturer; and (3) the system was not autoclaved because the pump was not resistant to the treatment.

After disinfection, the membranes were subjected to a chlorinated alkaline cleaning cycle (combination of Membra-chlore and Chloreco, Sani-Marc Inc., Victoriaville, Canada) following the manufacturer's protocol (150 ppm of free chlorine, $\mathrm{pH} 10.5,45^{\circ} \mathrm{C}, 30 \mathrm{~min}$ ). The cleaning cycle was performed at maximal flow rate $(7$ $\mathrm{L} / \mathrm{min}$, linear velocity around $0.9 \mathrm{~m} / \mathrm{s}$ ), under a turbulent flow (Reynolds number $\sim 4,000$ ). At the end of each filtration experiment, after a rinsing step with deionized water at room temperature, final cleaning cycle using the same conditions was also performed. The deionized water used for this study (conductivity $<5$ $\mu \mathrm{S} / \mathrm{cm}$ ) was generated by the central deionizing system (Culligan, Rosemont, IL) of the Pavillon Paul-Comtois (Université Laval), equipped with sand and charcoal filters, anion and cation exchange resins, and reverse osmosis membrane.

For each UF experiment, dairy fluids were filtered in concentration mode at a constant transmembrane pressure of $345 \mathrm{kPa}$ under a laminar flow regimen (Reynolds number between 700 to 3,000, depending on the filtered fluid) to favor the adhesion of bacteria in a short time. The recirculation rate was kept constant throughout the UF experiments to maintain a retentate crossflow velocity of approximately $0.5 \mathrm{~m} / \mathrm{s}$. We measured the permeation flux values $\left(J_{t}, \mathrm{~kg} / \mathrm{m}^{2}\right.$ per $\left.\mathrm{h}\right)$ of each cell hourly (duplicate) for each UF experiment as the mass of permeate $(\Delta m)$ collected by the filtration cells equipped with a $42-\mathrm{cm}^{2}$ filtration area $(A)$ in a given time $(\Delta t)$. An average value was calculated hourly (Eq. 1). 


$$
J_{t}=\frac{\Delta m_{1}+\Delta m_{2}+\Delta m_{3}+\Delta m_{4}}{4 \cdot \Delta t \cdot A} .
$$

Filtration performance were also evaluated by calculating the average permeate flux $\left(J_{A}, \mathrm{~kg} / \mathrm{m}^{2}\right.$ per $\left.\mathrm{h}\right)$ between the flux at the first $\left(J_{1}\right)$ and fifth $\left(J_{5}\right) \mathrm{h}$ of filtration for each experiment (Eq. 2):

$$
J_{A}=\frac{J_{1}+J_{5}}{2}
$$

and the total flux decline after 5 h (TFD, \%; Eq. 3).

$$
\mathrm{TFD}=\frac{J_{5}}{J_{1}} \times 100 .
$$

\section{Dairy Fluids and Operational Procedure}

Each replicate used dairy fluids from the same batch of fresh refrigerated raw milk obtained from a local dairy plant. When received, the lot of whole raw milk was divided into 10 - and $40-\mathrm{L}$ volumes. The $10-\mathrm{L}$ volume was used directly for whole raw milk UF experiments (d 1, Figure 2). The next day, the remaining whole raw milk was skimmed $[<0.05 \%$ (wt/wt) of fat $]$ at $45^{\circ} \mathrm{C}$ in a cream separator (model 619, DeLaval, Peterborough, ON, Canada) and pasteurized $\left(74^{\circ} \mathrm{C}\right.$ for $\left.16 \mathrm{~s}\right)$ in a UHT system (CFI-25, Chalinox, Sorel, QC, Canada). A vol- ume of $10 \mathrm{~L}$ was taken to perform the second UF experiment (d 2, Figure 2) and the remainder was used to produce cheese to generate cheese whey. The cheese was prepared starting from pasteurized skim milk to which a solution of calcium chloride [Calsol, $45 \%$ (wt/wt)] was added $[1 \%$ (wt/wt)] before its inoculation with mesophilic starters including Lactococcus lactis ssp. lactis and L. lactis ssp. cremoris [0.001\% (wt/vol); DOM culture, Centro Sperimentale del Latte, Zelo Buon Persico, Italia]. Microbial rennet $[0.01 \%$ (vol/vol), Chymax-M, $1000 \mathrm{IMCU} / \mathrm{mL}, \mathrm{CHR}-H a n s e n$, Milwaukee, WI] was added $1 \mathrm{~h}$ after the inoculation. The cheese curd was cut after a hardening time equivalent to the coagulation time. After cutting, the curd was heated for 45 min to a temperature of $38^{\circ} \mathrm{C}$ and stirred at this temperature for $15 \mathrm{~min}$. The fresh whey ( $\mathrm{pH}$ 6.4-6.5) was then collected and prefiltered using a cheese cloth to remove fines. A fraction of this prefiltered fresh whey $(10 \mathrm{~L})$ was then ultrafiltered (d 3, Figure 2), and the remaining volume $(10 \mathrm{~L})$ was finally pasteurized $\left(74^{\circ} \mathrm{C}\right.$ for $\left.16 \mathrm{~s}\right)$ before being ultrafiltered the next day (d 4, Figure 2).

Dairy fluids were ultrafiltered for $5 \mathrm{~h}$ at $10^{\circ} \mathrm{C}$, a temperature known to reduce microbial spoilage during filtration (Tang et al., 2015), or at $40^{\circ} \mathrm{C}$, a temperature known to be optimal for biofouling development in water systems (Melo and Bott, 1997). The volume concentration factor during UF of dairy fluids never exceeded 1.1 due to the low filtration area compared with the high volume of the feed. The fouling phenomena, or

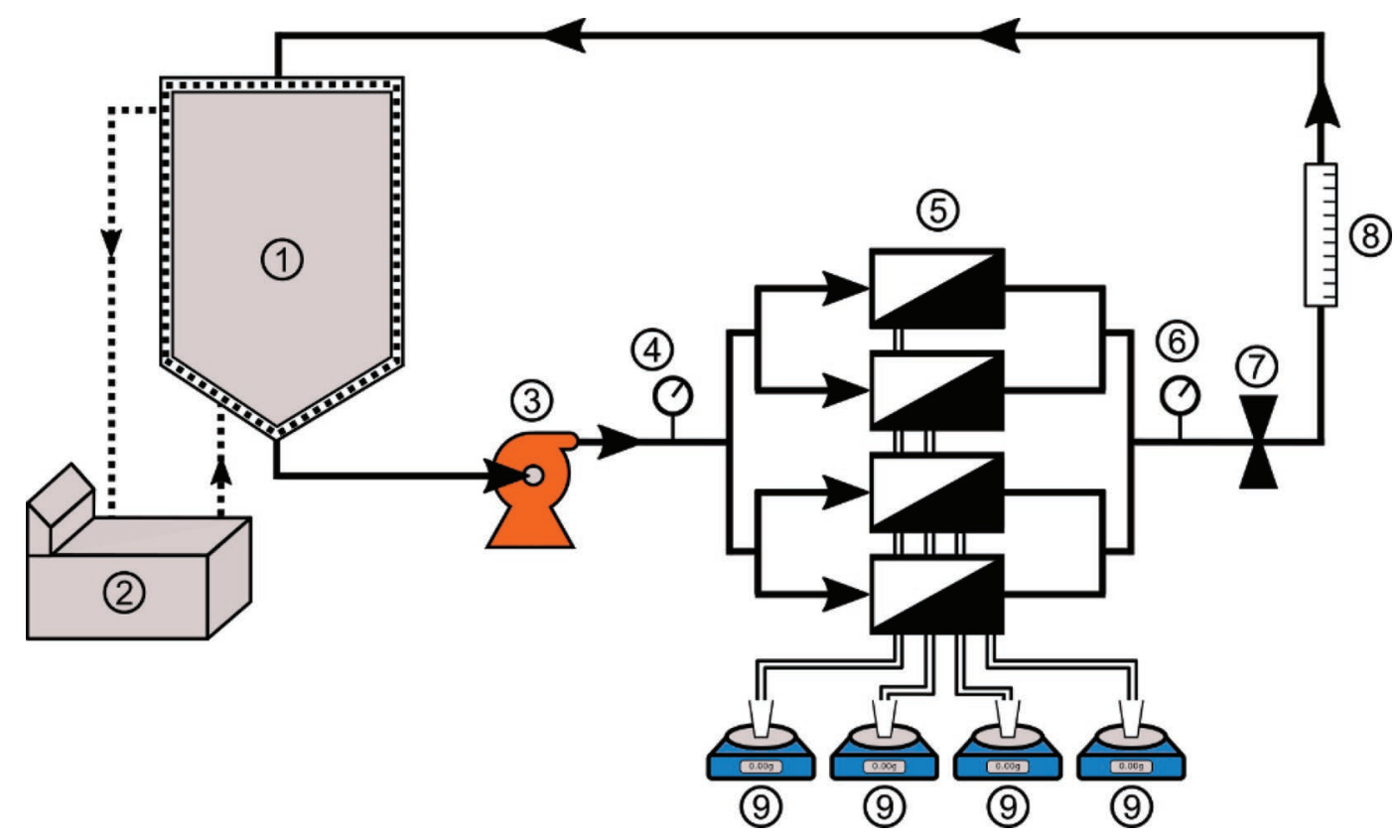

Figure 1. Laboratory-scale membrane system designed to study biofilm formation: (1) feed tank, (2) temperature-controlled water bath, (3) positive displacement diaphragm pump, (4) inlet pressure gauge, (5) filtration cells, (6) outlet pressure gauge, (7) restriction valve, (8) retentate flowmeter, and (9) individual permeate collection for each cell and flux measurement. Color version available online. 


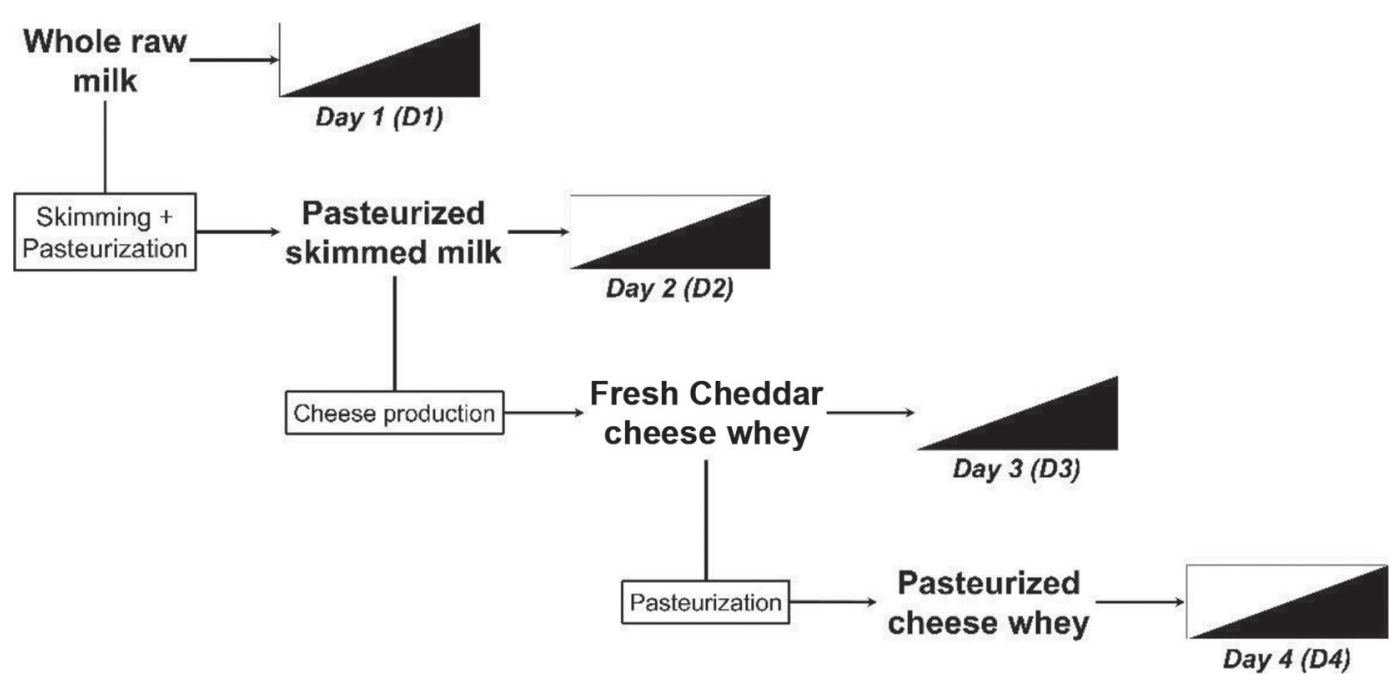

Figure 2. Experimental design for the preparation of different dairy fluids from the same batch lot of raw milk.

at least, the changes in concentration polarization, were thus rather limited.

\section{Sample Collection}

Retentate samples were taken at the beginning (during the first minute) and end (after $5 \mathrm{~h}$ ) of each filtration experiment for bacterial enumeration on standard plate count agar (BD Difco, Sparks, MD). Plates were incubated (Revco Elite II, Kendro Laboratory Products, Asheville, NC) at the filtration temperature for 48 h. After UF experiments, membrane coupons were collected before cleaning (after a 5-min rinsing step with deionized water) and after a chlorinated alkaline cleaning cycle and were stored at $-20^{\circ} \mathrm{C}$ until genomic DNA was extracted from adhered bacteria. This experimental design (Figure 2) was performed in triplicate for each filtration temperature $\left(10\right.$ and $\left.40^{\circ} \mathrm{C}\right)$.

\section{DNA Extraction and High-Throughput Sequencing}

The DNA extraction from UF membranes and filtered fluids, high-throughput sequencing targeting the 16S rRNA gene, and bioinformatics analysis (Mothur v1.35.0 [Schloss et al., 2009]) were carried out as described previously (Chamberland et al., 2016). The high-throughput sequencing was performed at Institut de biologie intégrative et des systèmes on a MiSeq sequencer (Illumina, San Diego, CA). Several controls were included to identify possible sources of contamination, including DNA extraction from the reagents used for DNA extraction (negative control named control), from an unused, factory new membrane and from a cleaned membrane (after its first cleaning cycle, before its first use). Computations were made on the supercomputers Colosse from Université Laval and Guillimin from McGill University, both managed by Calcul Québec and Compute Canada.

\section{Sequence Accession Number}

The $6,313,368$ raw reads of the $\mathrm{V} 6$-V8 region of $16 \mathrm{~S}$ rRNA genes sequenced from the membranes and dairy fluids were deposited in the NCBI Sequence Read Archive under accession number SRP075543.

\section{Statistical Analysis}

The statistical analysis of bacterial communities [permutational multivariate ANOVA (PERMANOVA) and diversity analysis] was done as described by Chamberland et al. (2016). Tukey's honest significance test $(\alpha=0.05)$ was performed (Agricolae package of $R$ ) to compare the average permeation flux, the total flux reduction, and the microbial load for every filtration experiment. Figures presented in this study were generated using RStudio software (v0.99) and the interactive tree of life (iTol) online tool (Letunic and Bork, 2011).

\section{RESULTS}

\section{Characterization of the Experimental Filtration Setup}

For all UF experiments, permeate flux values decreased linearly over the 5-h filtration time (Supplemental Figure S1; https://doi.org/10.3168/jds.201611829 ) and values obtained varied from 2.18 to $13.3 \mathrm{~kg} /$ $\mathrm{m}^{2}$ per h. Overall, higher average permeate fluxes were 
Table 1. Overview of flux changes (average permeate flux and total flux decline after $5 \mathrm{~h}$ ) and microbial growth on UF membrane of dairy fluids over $5 \mathrm{~h}$

\begin{tabular}{|c|c|c|c|c|c|}
\hline \multirow[b]{2}{*}{$\begin{array}{l}\text { Feed temperature } \\
\left({ }^{\circ} \mathrm{C}\right)\end{array}$} & \multirow[b]{2}{*}{ Filtered fluid } & \multirow[b]{2}{*}{$\begin{array}{l}\text { Average permeate flux } \\
\quad\left(\mathrm{kg} / \mathrm{m}^{2} \text { per } \mathrm{h}\right)\end{array}$} & \multirow[b]{2}{*}{$\begin{array}{l}\text { Total flux decline } \\
(\%)\end{array}$} & \multicolumn{2}{|c|}{$\begin{array}{l}\text { Microbial load in the retentate } \\
\qquad\left(\log _{10} \mathrm{cfu} / \mathrm{mL}\right)\end{array}$} \\
\hline & & & & $\begin{array}{l}\text { Before } \\
\text { filtration }\end{array}$ & $\begin{array}{l}\text { After } 5 \mathrm{~h} \\
\text { of filtration }\end{array}$ \\
\hline \multirow[t]{3}{*}{10} & Raw milk (d 1) & $2.39 \pm 0.12^{\mathrm{e}}$ & $0.30 \pm 1.48^{\mathrm{b}}$ & $3.61 \pm 0.20^{\mathrm{bc}}$ & $4.22 \pm 0.37^{\mathrm{bc}}$ \\
\hline & Pasteurized skim milk (d 2) & $1.97 \pm 0.07^{\mathrm{e}}$ & $9.42 \pm 15.97^{\mathrm{ab}}$ & $2.53 \pm 0.29^{\mathrm{c}}$ & $2.94 \pm 0.37^{\mathrm{c}}$ \\
\hline & Fresh whey (d 3) & $7.01 \pm 0.06^{\mathrm{c}}$ & $18.54 \pm 1.01^{\mathrm{ab}}$ & $6.66 \pm 0.26^{\mathrm{a}}$ & $6.94 \pm 0.24^{\mathrm{a}}$ \\
\hline \multirow{3}{*}{40} & Pasteurized skim milk (d 2) & $4.39 \pm 0.37^{\mathrm{d}}$ & $12.45 \pm 4.39^{\mathrm{ab}}$ & $2.30 \pm 0.44^{\mathrm{c}}$ & $6.36 \pm 0.50^{\mathrm{ab}}$ \\
\hline & Fresh whey (d 3) & $11.54 \pm 0.06^{\mathrm{a}}$ & $23.96 \pm 2.84^{\mathrm{ab}}$ & $5.66 \pm 0.81^{\mathrm{ab}}$ & $7.32 \pm 0.50^{\mathrm{a}}$ \\
\hline & Pasteurized whey (d 4) & $9.06 \pm 0.38^{\mathrm{b}}$ & $27.41 \pm 2.69^{\mathrm{ab}}$ & $2.13 \pm 0.24^{\mathrm{c}}$ & $4.16 \pm 0.70^{\mathrm{bc}}$ \\
\hline
\end{tabular}

${ }^{\mathrm{a} e}$ Means within a column with different superscripts differ $( \pm 1 \mathrm{SE}$, Tukey test, $P<0.05)$.

obtained during the UF of both fresh and pasteurized whey at $40^{\circ} \mathrm{C}\left(\mathrm{d} 3,40^{\circ} \mathrm{C}\right.$; and $\mathrm{d} 4,40^{\circ} \mathrm{C}$; Table 1$)$. The pasteurization seemed to reduce the average permeate flux during UF of whey, but the differences were only significant at $40^{\circ} \mathrm{C}(P<0.05)$. At the end of the 5 -h period, the permeate flux during $\mathrm{d} 4,40^{\circ} \mathrm{C}$ was slightly higher than during UF d $3,10^{\circ} \mathrm{C}(9.06$ and $7.01 \mathrm{~kg} /$ $\mathrm{m}^{2}$ per $\mathrm{h}$, respectively), but the TFD during $\mathrm{d} 3$ to $10^{\circ} \mathrm{C}$ was lower.

Permeate fluxes during milk UF were also higher at $40^{\circ} \mathrm{C}\left(\mathrm{d} 1,40^{\circ} \mathrm{C}\right.$; and $\mathrm{d} 2,40^{\circ} \mathrm{C}, P<0.05$; Table 1$)$. However, contrary to whey UF, milk pasteurization did not noticeably affect the average permeate flux after $5 \mathrm{~h}(P<0.05)$. For a given temperature $\left(10\right.$ or $\left.40^{\circ} \mathrm{C}\right)$, differences between average permeate flux during d 1 and 2 were not significant $(P<0.05$, Table 1$)$. For all UF experiments, the lowest TFD were observed during d 1 experiments $(P<0.05$; Table 1$)$.

Prior to filtration, the highest microbial load was found in fresh whey (up to $6.66 \log _{10} \mathrm{cfu} / \mathrm{mL}$ ), whereas pasteurized whey had the lowest count $\left(2.13 \log _{10} \mathrm{cfu} /\right.$ $\mathrm{mL}, P<0.05$, Table 1$)$. The raw milk used in this study was fresh (less than $3.63 \log _{10} \mathrm{cfu} / \mathrm{mL}$ ); pasteurization of the milk only reduced its microbial load by approximately $1 \log _{10} \mathrm{cfu} / \mathrm{mL}$. Microbial growth rate in the retentate was slower during filtrations performed at $10^{\circ} \mathrm{C}$, where the bacterial population never grew more than $1 \log _{10} \mathrm{cfu} / \mathrm{mL}$ in $5 \mathrm{~h}$. At $40^{\circ} \mathrm{C}$, the increase varied from 1.66 to $4.06 \log _{10} \mathrm{cfu} / \mathrm{mL}$ and was always higher than filtrations performed at $10^{\circ} \mathrm{C}$ using the same fluid.

\section{Diversity Among Young Communities on Membranes and in Filtered Fluids}

Prior to the filtration experiments, pasteurized milk was the fluid with the highest operational taxonomic units observed $\left(\mathrm{S}_{\mathrm{obs}}, 2,747\right.$; Supplemental Table S1; https://doi.org/10.3168/jds.2016-11829), but also the lowest coverage (Good's coverage index of $87.3 \%$ ), explaining its nonsaturated rarefaction curve (Supplemental Figure S2; https://doi.org/10.3168/jds.201611829). A higher $\mathrm{S}_{\text {obs }}\left(1,015\right.$ to 1,539 at $10^{\circ} \mathrm{C}$ and 254 to 826 at $40^{\circ} \mathrm{C}$ ) was calculated and estimated (Chao 1 richness index; $5,241.53$ to $6,207.28$ at $10^{\circ} \mathrm{C}$ and $1,117.61$ to $3,238.85$ at $40^{\circ} \mathrm{C}$ ) in samples from those membranes used to filter fluids at the lower temperature $\left(10^{\circ} \mathrm{C}\right.$; Supplemental Table S1; https://doi. org/10.3168/jds.2016-11829). The diversity of bacteria observed on membranes (inverse Simpson diversity index) for each fluid was also higher when the feed temperature was lower (Supplemental Table S1). However, samples generated at $10^{\circ} \mathrm{C}$ had lower coverage, from 92.7 to $94.7 \%$, in contrast to 96.0 to $98.8 \%$ for membranes used at $40^{\circ} \mathrm{C}$. On the other hand, the proportion of unclassified bacteria at the phylum level was low $(<0.43 \%$; Table 2$)$.

Statistically, the membrane cleaning cycles did not significantly influence the composition of early bacterial communities on the membranes $(P=0.461$, PERMANOVA). This explains why all the bacterial communities presented in this study are those found on membranes after cleaning to simplify the manuscript. Quantitatively, it is hypothesized that the number of bacteria on membranes is lower after cleaning because fewer $\mathrm{S}_{\text {obs }}$ were calculated on the cleaned membrane compared with the new membrane (250 and 1,782, respectively). However, the quantification of bacteria adhering to membranes was not done in this study.

Because analyzing pioneer colonizer bacteria involves working with low DNA concentrations, the potential effect of residual DNA present in the laboratory during DNA extractions was tested by sequencing a control sample containing only the DNA from extraction reagents. The genus Delftia was dominant among the 327 
Table 2. Proportions (percentage of sequenced reads) of the 10 most abundant bacterial genera found on UF membranes after chlorinated alkaline cleaning at $10^{\circ} \mathrm{C}$ and $40^{\circ} \mathrm{C}$

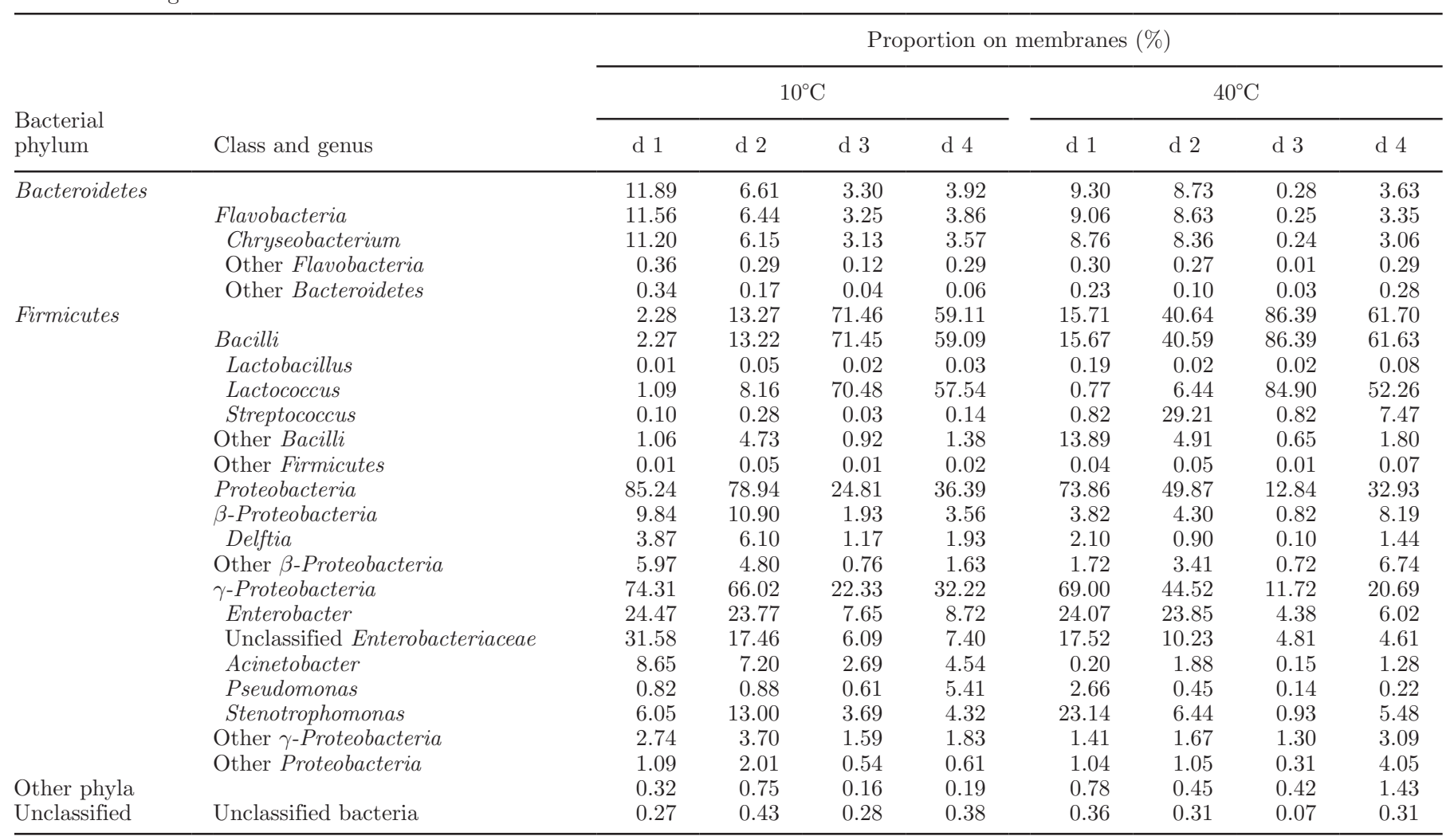

$\mathrm{S}_{\text {obs }}$ observed in the control sample $(80.7 \%$, Figure 3$)$ but was only a minor genus observed on membranes (proportions from 0.02 to $6.10 \%$ ). We therefore considered it to be a false positive on membrane samples and in filtered fluids.

\section{Influence of the Nature of the Filtered Fluid}

The 3 major phyla observed on membranes were $B a c$ teroidetes, Firmicutes, and Proteobacteria. The phyla Proteobacteria and Bacteroidetes were predominantly found on milk processing membranes, whereas Firmicutes were dominant on whey processing membranes (Table 2). Among these phyla, $\gamma$-Proteobacteria, Bacilli, and Flavobacteria were dominant classes. According to the PERMANOVA, the nature of the filtered fluid was highly significant and would explain the major variance (36.15\%, $P<0.001)$ observed among the young communities analyzed in this study (Table 3 ).

\section{Milk Processing Membranes (d 1 and 2)}

During $\mathrm{d} 1$ and 2 assays, the bacteria adhering to membranes essentially all belonged to the $\gamma$-Proteobacteria class $\left(78.94\right.$ to $85.24 \%$ at $10^{\circ} \mathrm{C}$ and 49.87 to $73.86 \%$ at $40^{\circ} \mathrm{C}$ ) and the Flavobacteria class (6.61 to $11.89 \%$ at $10^{\circ} \mathrm{C}$ and 8.73 to $9.30 \%$ at $40^{\circ} \mathrm{C}$; Table 2). The main genera found on these membranes were Enterobacter (23.77 to 24.47\%), an unclassified Enterobacteriaceae (10.23 to $31.58 \%$ ) and Chryseobacterium (6.15 to $11.20 \%$; Table 2). Day 1 membranes always had a higher proportion of Proteobacteria compared with d 2 membranes. Conversely, d 2 membranes had higher proportions of Firmicutes due to a higher proportion of Streptococcus and Lactococcus genera (Table 1). In fact, higher proportions of Streptococcus (and Lactococcus on d 2) were observed on membranes used to filter pasteurized fluids (d 2 and 4) than membranes used to filter raw fluids (d 1 and 3 ).

\section{Whey Processing Membranes (d 3 and 4)}

During d 3 and 4 filtrations, the Lactococcus genus was dominant on membranes. Higher proportions of Lactococcus were found after UF of fresh whey (d 3) at $40^{\circ} \mathrm{C}$ (84.90\%; Table 2). During whey processing, $\gamma$-Proteobacteria were not as numerous as Bacilli, but they were more abundant on membranes after UF of pasteurized whey (d 4) compared with UF of fresh whey (d 3). 
Table 3. Governing factors affecting the diversity of pioneer colonizer bacteria observed on UF membranes after $5 \mathrm{~h}$ of filtration

\begin{tabular}{lcr}
\hline & \multicolumn{2}{c}{ Variance explained (\%) } \\
\cline { 2 - 2 } Factor & All membrane samples & \\
\hline Fluid & $P$-value \\
Temperature & 36.15 & $<0.001$ \\
Cleaning & 5.09 & 0.007 \\
Fluid $\times$ temperature & 1.26 & 0.461 \\
Residuals & 5.41 & 0.173 \\
Total & 48.87 & \\
\hline
\end{tabular}

\section{Feed Temperature During Ultrafiltration}

The feed temperature was a significant factor, explaining $5.07 \%$ of variations among early communities observed $(P=0.007$, Table 3$)$. When operating the system at the cold temperature $\left(10^{\circ} \mathrm{C}\right)$, the overall proportion of $\gamma$-Proteobacteria on membranes was higher, for example, $22.33 \%$ of the bacteria on the $\mathrm{d} 3$ membrane at $10^{\circ} \mathrm{C}$ versus $11.72 \%$ at $40^{\circ} \mathrm{C}$ (Table 2 ). As mentioned previously, higher proportions of the Streptococcus genus were found on d 2 and 4 compared with assays performed on $\mathrm{d} 1$ and 3 , respectively. These differences were accentuated at $40^{\circ} \mathrm{C}$ where Streptococcus represented 29.21 and $7.47 \%$ of the community formed on membranes during d 2 and 4 , respectively, whereas it represented $0.82 \%$ after both d 1 and 3 experiments. As previously mentioned, the microbial load in the milk retentate was always significantly higher in retentate obtained at 40 versus $10^{\circ} \mathrm{C}$.

\section{Effect of the Bacterial Environment of the Filtration System}

No matter which operating parameter was used during UF (the nature of the filtered fluid, the feed temperature, or the cleaning cycle) and despite daily disinfection [ethanol $70 \%$ (vol/vol)] of the filtration system, 5 genera not detected (or found in trace amounts) in the filtered fluid were present on each membrane after UF (Figure 3). These genera (Enterobacter, an unclassified Enterobacteriaceae, Stenotrophomonas, Acinetobacter, and Pseudomonas) represented 10.4 to $71.6 \%$ of the bacteria on membranes (Table 2). In previous unpublished work, Stenotrophomonas, Enterobacter,
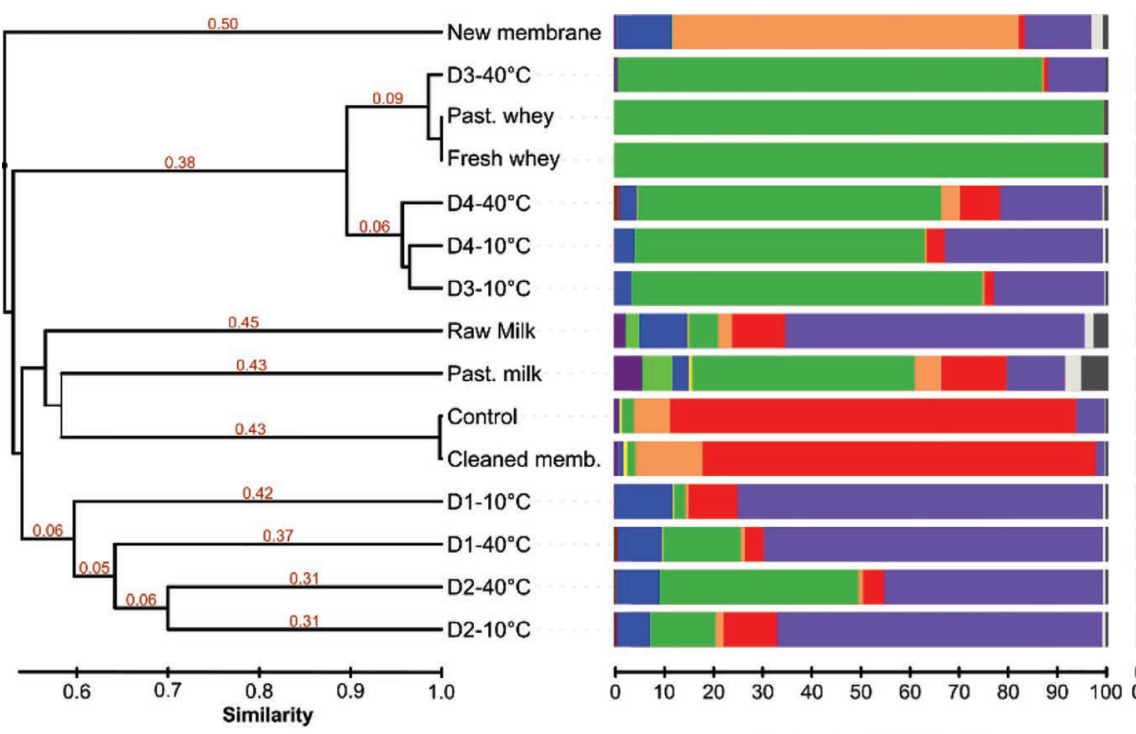

Class proportions (\%)
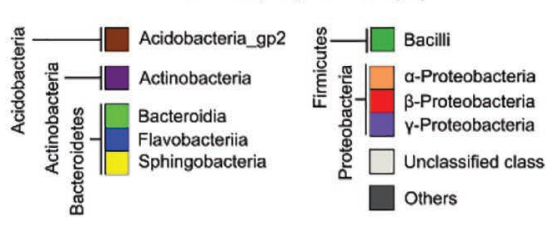

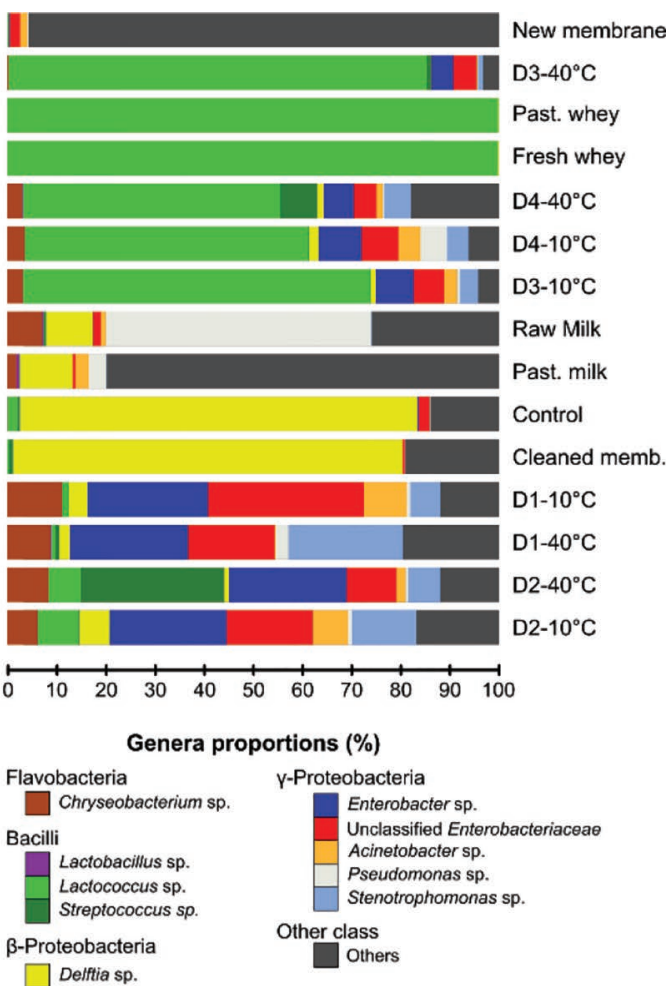

Figure 3. Combined stack chart and dendrogram presenting relative proportions (percentage of sequence reads) of major bacterial classes and genera on UF membranes after the cleaning cycle performed after $5 \mathrm{~h}$ of UF experiments. Distances below 0.05 are not provided and communities on membranes (memb.) sampled before the cleaning cycle are not presented to simplify the analysis because no significant differences were found between the cleaned coupons. Past. = pasteurized; D1, D2, D3, D4 = d 1, 2, 3, 4, respectively. 
and Pseudomonas genera were found in the deionized water source used to clean the system.

As mentioned previously, virgin UF membranes were not sterile and the major genera found on them were Sphingomonas sp. (30.9\%) and Novosphingobium sp. $(22.2 \%)$, but their proportions were reduced on the cleaned membrane (3.92 and $<0.01 \%$, respectively) and found in low numbers on membranes after filtration experiments ( $<0.01$ to $1.23 \%$ and $<0.01$ to $0.03 \%$, respectively).

\section{DISCUSSION}

\section{Effect of Fouling Incidence on Biofilm Formation}

In dairy processing, the temperature of the feed and the heat-treatments used are the main alternatives for controlling membrane biofouling issues but there is a trade-off between system performance and quality of the retentates (e.g., protein concentrate from milk or whey). Even if higher temperatures increase the permeate flux (Pompei et al., 1973), it is now accepted that retentates produced at lower temperatures have better qualities in terms of less protein denaturation and slower microbial growth (Luo et al., 2015; Tang et al., 2015). In addition, lowering the microbial load by pasteurizing the feed may help by reducing adhesion of metabolically active bacteria to membranes (Koop et al., 1989; Al-Juboori and Yusaf, 2012). However, as observed in this study, the pasteurization of the whey significantly reduced permeate fluxes $(P<0.05)$, possibly as a result of whey protein denaturation or formation of $\beta$-lactoglobulin aggregates (Steinhauer et al., 2015). Filtering unpasteurized whey at $10^{\circ} \mathrm{C}$ may be an interesting compromise between performance and quality since the average permeate fluxes during $\mathrm{d} 3,10^{\circ} \mathrm{C}$ and $\mathrm{d} 4,40^{\circ} \mathrm{C}$ were similar, even if they were statistically different $(P<0.05)$ after $5 \mathrm{~h}$ of filtration. However, filtration experiments with longer processing times are needed to assess the potential of biofouling at $10^{\circ} \mathrm{C}$ with unpasteurized whey.

\section{Membrane Bacterial Profile as a Function of Dairy Fluid Properties}

As dairy fluids go through the cheese processing line, numerous conditions impose a selective pressure on their microflora (heat, oxidative conditions, competition with the starter culture, nutrient availability), modulating bacterial composition and influencing bacterial adherence to membranes (Chamberland et al., 2016). The effects of some of these stresses (pas- teurization and cheesemaking) can be detected in the general portrait of pioneer colonizer bacteria adhering to membranes after filtration of various dairy fluids at different temperatures. The nature of the filtered fluid had the greatest effect on the variances observed in the early bacterial communities found on membranes because the adherent bacteria detected depended on which bacteria were in the different fluids (Marchand et al., 2012). The proportions of colonizer bacteria found on membranes were, however, mostly different from those observed in filtered fluids (Zhang et al., 2011), showing the role of specific colonizer bacteria during the early stages of biofilm formation (Martiny et al., 2003).

Of the factors affecting the nature of the filtered fluid, the inherent microflora of both milk and whey had major effects on the composition of early communities observed on membrane samples. Raw milk is rapidly cooled on collection and stored at cold temperatures $\left(<4^{\circ} \mathrm{C}\right)$ at the farm and dairy plant to slow down microbial growth, which explains the high proportion of psychrotrophic bacteria (Champagne et al., 1994). Conversely, whey is generated in a mesophilic temperature range and is dominated by the cheese starter culture (Lactococcus sp.). The major psychrotrophic contaminant in the dairy industry is Pseudomonas spp. (Raats et al., 2011; Marchand et al., 2012; Quigley et al., 2013). This genus was not dominant on membranes used for processing milk, but other bacteria belonging to the $\gamma$-Proteobacteria class, the major bacterial class found on membranes used for filtering milk in this study, have previously been recognized as the primary colonizer on filtration membranes (Hörsch et al., 2005). In a dairy processing plant, $\gamma$-Proteobacteria are associated with cold environments such as the cheese rind surface during ripening at $12^{\circ} \mathrm{C}$ (Wolfe et al., 2014; Calasso et al., 2016), which could explain why a higher proportion of $\gamma$-Proteobacteria was observed on membranes used to filter whey at the colder temperature $\left(10^{\circ} \mathrm{C}\right)$.

Pasteurization of both fluids also affected the bacterial portrait of d 2 and 4 membranes, notably increasing the ratio of heat-resistant bacteria such as Streptococcus spp. This is especially noticeable during filtration at $40^{\circ} \mathrm{C}$, which is near the optimum growth temperature of many Streptococcus spp. (Beal et al., 1989). However, as suggested by Quigley et al. (2013), pasteurization reduces the microbial concentration of many heat sensitive bacteria, or puts them in a viable but nonculturable state rather than killing them. This could explain the similar patterns observed with membranes that filtered the same fluid (pasteurized or not), especially membranes used for whey filtration. 


\section{Influence of the Environmental Microflora of the Dairy Plant}

In the cheese industry, despite producing a similar range of products, a specific microflora exists in each dairy plant, affecting the microflora of the final products (Bokulich and Mills, 2013). In this study, operational parameters during UF explained approximately half of the composition of early bacterial communities found on membranes. The remainder could be explained by other operational parameters not studied here, such as the membrane type (Vanysacker et al., 2014), fluid velocity (Vrouwenvelder et al., 2009), or transmembrane pressure (Saeki et al., 2016). However, there might be a processing environmental factor to be considered, as observed for membrane bioreactor systems (Wang et al., 2012; Jo et al., 2016).

Of the bacteria initially found in the raw milk, only the genus Chryseobacterium was persistent throughout milk processing in the model cheesemaking plant. The Sphingomonas and Novosphingobium genera, present on the virgin membranes used for this study, were only found in low proportions on membranes after the cleaning cycle (cleaned membrane sample) and filtration experiments. Conversely, 5 genera constantly adhered to membranes even if they were not detected in fluids before filtration, suggesting their natural presence in the filtration processing environment (despite numerous disinfection and cleaning cycles) or in the deionized water used for the cleaning steps.

\section{CONCLUSIONS}

The use of a laboratory-scale crossflow filtration system designed for this study allowed us to characterize the effects of dairy fluids on biofilm formation in a controlled environment. The use of a metabarcoding approach allowed us to accurately identify specific pioneer bacteria that colonized membranes following UF of dairy fluids, which have an inherently complex microflora. Future prevention strategies should consider the nature of the fluid to be filtered and the temperature of the feed, as well as the environmental microflora of the dairy plant because it probably contains natural colonizer bacteria adapted to the filtration environment. After identifying the pioneer bacteria, the challenge will be to find ways to minimize their adhesion to membranes and, eventually, to limit their production of problematic extracellular polymeric substances. Developing specific cleaning agents, such as enzymes that target the cell walls of the bacteria identified in this study, could potentially be a good treatment tool. However, understanding the sociomicrobiology behind biofilm development will be necessary to design preven- tion strategies specific to the microbial environment of dairy plants and their processing conditions.

\section{ACKNOWLEDGMENTS}

This work was supported by the Natural Sciences and Engineering Research Council of Canada (NSERC) and Novalait thourgh the NSERC-Novalait Industrial Research Chair on Process Efficiency in Dairy Technology (Grant IRCPJ 461630-12 to Yves Pouliot); the Canadian Dairy Commission and Novalait through a MS scholarship to Julien Chamberland (Grant 187210); the Canada Foundation for Innovation (CFI), Le Ministère de l'Économie, de l'Innovation et des Exportations du Québec (MESI); and the Fonds de recherche du Québec-Nature et technologies (FRQ-NT) for the operation of the supercomputers of Calcul Québec. The authors thank Laurence Pouliot (intern, Université Laval, Québec, QC, Canada) for her great help in operating the laboratory-scale crossflow filtration system and Biena (St-Hyacinthe, QC, Canada) for providing the cheese starter cultures.

\section{REFERENCES}

Al-Juboori, R. A., and T. Yusaf. 2012. Biofouling in RO system: Mechanisms, monitoring and controlling. Desalination 302:1-23. https://doi.org/10.1016/j.desal.2012.06.016.

Anand, S., and D. Singh. 2013. Resistance of the constitutive microflora of biofilms formed on whey reverse-osmosis membranes to individual cleaning steps of a typical clean-in-place protocol. J. Dairy Sci. 96:6213-6222. https://doi.org/10.3168/jds.2013-7012.

Anand, S., D. Singh, M. Avadhanula, and S. Marka. 2014. Development and control of bacterial biofilms on dairy processing membranes. Compr. Rev. Food Sci. Food Saf. 13:18-33. https://doi. org/10.1111/1541-4337.12048.

Beal, C., P. Louvet, and G. Corrieu. 1989. Influence of controlled pH and temperature on the growth and acidification of pure cultures of Streptococcus thermophilus 404 and Lactobacillus bulgaricus 398. Appl. Microbiol. Biotechnol. 32:148-154. https://doi.org/10.1007/ BF00165879.

Bokulich, N. A., and D. A. Mills. 2013. Facility-specific "house" microbiome drives microbial landscapes of artisan cheesemaking plants. Appl. Environ. Microbiol. 79:5214-5223. https://doi.org/10.1128/ AEM.00934-13.

Calasso, M., D. Ercolini, L. Mancini, G. Stellato, F. Minervini, R. Di Cagno, M. De Angelis, and M. Gobbetti. 2016. Relationships among house, rind and core microbiotas during manufacture of traditional Italian cheeses at the same dairy plant. Food Microbiol. 54:115-126. https://doi.org/10.1016/j.fm.2015.10.008.

Chamberland, J., M.-H. Lessard, A. Doyen, S. Labrie, and Y. Pouliot. 2016. A sequencing approach targeting the 16S rRNA gene unravels the biofilm composition of spiral-wound membranes used in the dairy industry. Dairy Sci. Technol. https://doi.org/10.1007/ s13594-016-0305-2.

Champagne, C. P., R. R. Laing, D. Roy, A. A. Mafu, and M. W. Griffiths. 1994. Psychrotrophs in dairy products: Their effects and their control. Crit. Rev. Food Sci. Nutr. 34:1-30. 10.1080/10408399409527671.

Farhat, N. M., J. S. Vrouwenvelder, M. C. M. Van Loosdrecht, S. S. Bucs, and M. Staal. 2016. Effect of water temperature on biofouling development in reverse osmosis membrane systems. Water Res. 103:149-159. https://doi.org/10.1016/j.watres.2016.07.015. 
Flemming, H.-C. 1997. Reverse osmosis membrane biofouling. Exp. Therm. Fluid Sci. 14:382-391. https://doi.org/10.1016/S08941777(96)00140-9.

Herzberg, M., S. Kang, and M. Elimelech. 2009. Role of extracellular polymeric substances (EPS) in biofouling of reverse osmosis membranes. Environ. Sci. Technol. 43:4393-4398. https://doi. org/10.1021/es900087j.

Hörsch, P., A. Gorenflo, C. Fuder, A. Deleage, and F. H. Frimmel. 2005. Biofouling of ultra- and nanofiltration membranes for drinking water treatment characterized by fluorescence in situ hybridization (FISH). Desalination 172:41-52. https://doi.org/10.1016/j. desal.2004.05.009.

Jo, S. J., H. Kwon, S.-Y. Jeong, C.-H. Lee, and T. G. Kim. 2016. Comparison of microbial communities of activated sludge and membrane biofilm in 10 full-scale membrane bioreactors. Water Res. 101:214-225. https://doi.org/10.1016/j.watres.2016.05.042.

Koop, H. M., M. Valentijn-Benz, A. V. Nieuw Amerongen, P. A. Roukema, and J. De Graaff. 1989. Aggregation of 27 oral bacteria by human whole saliva. Influence of culture medium, calcium, and bacterial cell concentration, and interference by autoaggregation. Antonie van Leeuwenhoek 55:277-290. https://doi.org/10.1007/ BF00404751.

Letunic, I., and P. Bork. 2011. Interactive Tree Of Life v2: Online annotation and display of phylogenetic trees made easy. Nucleic Acids Res. 39:W475-W478. https://doi.org/10.1093/nar/gkr201.

Luo, X., L. Ramchandran, and T. Vasiljevic. 2015. Lower ultrafiltration temperature improves membrane performance and emulsifying properties of milk protein concentrates. Dairy Sci. Technol. 95:15-31. https://doi.org/10.1007/s13594-014-0192-3.

Marchand, S., J. De Block, V. De Jonghe, A. Coorevits, M. Heyndrickx, and L. Herman. 2012. Biofilm formation in milk production and processing environments; influence on milk quality and safety. Compr. Rev. Food Sci. Food Saf. 11:133-147. https://doi. org/10.1111/j.1541-4337.2011.00183.x.

Martiny, A. C., T. M. Jørgensen, E. Arvin, S. Molin, and H.-J. Albrechtsen. 2003. Long-term succession of structure and diversity of a biofilm formed in a model drinking water distribution system. Appl. Environ. Microbiol. 69:6899-6907. https://doi.org/10.1128/ AEM.69.11.6899.

Melo, L. F., and T. R. Bott. 1997. Biofouling in water systems. Exp. Therm. Fluid Sci. 14:375-381. https://doi.org/10.1016/S08941777(96)00139-2.

Mittelman, M. W. 1998. Structure and functional characteristics of bacterial biofilms in fluid processing operations. J. Dairy Sci. 81:2760-2764. https://doi.org/10.3168/jds.S0022-0302(98)758333.

Pan, Y., F. Breidt, and S. Kathariou. 2006. Resistance of Listeria monocytogenes biofilms to sanitizing agents in a simulated food processing environment. Appl. Environ. Microbiol. 72:7711-7717. https://doi.org/10.1128/AEM.01065-06.

Pompei, C., P. Resmini, and C. Peri. 1973. Skim milk protein recovery and purification by ultrafiltration, Influence of temperature on permeation rate and retention. J. Food Sci. 38:867-870. https:// doi.org/10.1111/j.1365-2621.1973.tb02095.x.

Quigley, L., R. McCarthy, O. O'Sullivan, T. P. Beresford, G. F. Fitzgerald, R. P. Ross, C. Stanton, and P. D. Cotter. 2013. The microbial content of raw and pasteurized cow milk as determined by molecular approaches. J. Dairy Sci. 96:4928-4937. https://doi. org $/ 10.3168 /$ jds.2013-6688

Raats, D., M. Offek, D. Minz, and M. Halpern. 2011. Molecular analysis of bacterial communities in raw cow milk and the impact of refrigeration on its structure and dynamics. Food Microbiol. 28:465-471. https://doi.org/10.1016/j.fm.2010.10.009.

Saeki, D., H. Karkhanechi, H. Matsuura, and H. Matsuyama. 2016. Effect of operating conditions on biofouling in reverse osmosis membrane processes: Bacterial adhesion, biofilm formation, and permeate flux decrease. Desalination 378:74-79. https://doi. org/10.1016/j.desal.2015.09.020.

Schloss, P. D., S. L. Westcott, T. Ryabin, J. R. Hall, M. Hartmann, E. B. Hollister, R. A. Lesniewski, B. B. Oakley, D. H. Parks, C. J Robinson, J. W. Sahl, B. Stres, G. G. Thallinger, D. J. Van Horn, and C. F. Weber. 2009. Introducing mothur: Open-source, platform-independent, community-supported software for describing and comparing microbial communities. Appl. Environ. Microbiol. 75:7537-7541. https://doi.org/10.1128/AEM.01541-09.

Simões, M., L. C. Simões, and M. J. Vieira. 2010. A review of current and emergent biofilm control strategies. LWT Food Sci. Technol. (Campinas) 43:573-583. https://doi.org/10.1016/j. lwt.2009.12.008.

Steinhauer, T., M. Marx, K. Bogendörfer, and U. Kulozik. 2015. Membrane fouling during ultra- and microfiltration of whey and whey proteins at different environmental conditions: The role of aggregated whey proteins as fouling initiators. J. Membr. Sci. 489:2027. https://doi.org/10.1016/j.memsci.2015.04.002.

Tang, X., S. Flint, R. Bennett, J. Brooks, and S. N. M. Zain. 2015. Biofilm contamination of ultrafiltration and reverse osmosis plant. Pages 138-153 in Biofilms in the Dairy Industry. Wiley Blackwell, West Sussex, UK.

Teh, K. H., S. Flint, J. Palmer, P. Andrewes, P. Bremer, and D. Lindsay. 2014. Biofilm-An unrecognised source of spoilage enzymes in dairy products? Int. Dairy J. 34:32-40. https://doi.org/10.1016/j. idairyj.2013.07.002.

Vanysacker, L., P. Declerck, M. R. Bilad, and I. F. J. Vankelecom. 2014. Biofouling on microfiltration membranes in MBRs: Role of membrane type and microbial community. J. Membr. Sci. 453:394401. https://doi.org/10.1016/j.memsci.2013.11.024.

Vrouwenvelder, J. S., C. Hinrichs, W. G. J. Van der Meer, M. C. M. Van Loosdrecht, and J. C. Kruithof. 2009. Pressure drop increase by biofilm accumulation in spiral wound RO and NF membrane systems: Role of substrate concentration, flow velocity, substrate load and flow direction. Biofouling 25:543-555. https://doi. org $/ 10.1080 / 08927010902972225$.

Wang, X., M. Hu, Y. Xia, X. Wen, and K. Ding. 2012. Pyrosequencing analysis of bacterial diversity in 14 wastewater treatment systems in China. Appl. Environ. Microbiol. 78:7042-7047. https://doi. org/10.1128/AEM.01617-12.

Wolfe, B. E., J. E. Button, M. Santarelli, and R. J. Dutton. 2014. Cheese rind communities provide tractable systems for in situ and in vitro studies of microbial diversity. Cell 158:422-433. https:// doi.org/10.1016/j.cell.2014.05.041.

Zhang, M., S. Jiang, D. Tanuwidjaja, N. Voutchkov, E. M. V. Hoek, and B. Cai. 2011. Composition and variability of biofouling organisms in seawater reverse osmosis desalination plants. Appl. Environ. Microbiol. 77:4390-4398. https://doi.org/10.1128/AEM.00122-11. 